The Quarterly Journal of Austrian Economics

Volume 24 | NO. 2 | 317-347 | SuMmer 2021 WWW.QJAE.ORG

\title{
An Anatomy of Failure: China's Wind Power Development
}

\author{
Jonas Grafström*
}

JEL Classification: P21, O32, Q55, Q58, B53

\begin{abstract}
АвsтRAcт: China is currently the world's largest installer of wind power. However, with twice the installed wind capacity compared to the United States in 2015, the Chinese produce less power. The question is: Why is this the case? This article shows that Chinese grid connectivity is low, Chinese firms have few international patents, and that export is low even though production capacity far exceeds domestic production needs. Using the tools of Austrian economics, China's wind power development from 1980 to 2016 is documented and analyzed from three angles: (a) planning and knowledge problems, (b) unproductive entrepreneurship, and (c) bureaucracy and government policy. From a theoretical standpoint, both a planning problem and an entrepreneurial problem are evident where governmental policies create misallocation of resources and a hampering of technological development.
\end{abstract}

\section{INTRODUCTION}

The headline of a 1953 article by Peter Wiles in Foreign Affairs had stated that "The Soviet Economy Outpaces the West." Based on the official Soviet statistics, the GDP growth numbers suggested

\footnotetext{
* Jonas Grafström (jonas.grafstrom@ratio.se) is a researcher at the Ratio Institute and an assistant professor at Luleå University of Technology. He is also a visiting fellow at the Oxford Institute for Energy Studies. He is thankful for comments by John Taylor, Nils Karlson, and Christopher Coyne. All errors are solely upon the author.
} 
that the Soviet Union could plausibly outgrow the West, but as later revealed, the numbers did not match reality (Levy and Peart 2011). What Peter Wiles and numerous scholars at the time did not see were the cracks in the Soviet economic system (Boettke 2001, 2002a; Huerta de Soto [1992] 2010). The Soviet Union is gone; the slightly younger, seventy-year-old People's Republic of China is still (to a large extent ${ }^{1}$ ) a planned economy that by some accounts appears to be on the verge of outpacing the West. However, cracks can be seen in the Chinese economy, as illustrated by its wind power industry, which is analyzed in this paper. ${ }^{2}$

There are many problems in the Chinese wind power expansion effort (see e.g., Zeng et al. 2015; Karltorp, Guo, and Sandén 2017). The installed wind capacity in China has long been twice that of the United States (IRENA 2018). However, despite having twice the installed capacity, China produces less power than the US. Grid connectivity is low, Chinese firms have few international patents, and exports are low even though production capacity far exceeds domestic needs (Cass 2009; Zhe 2011; Xingang et al. 2012; Sun et al. 2015; Zeng et al. 2015; Karltorp, Guo, and Sandén 2017; Lam, Branstetter, and Azevedo 2017; Zhang et al. 2017).

Despite robust government support, wind power in China is obstructed by various barriers like quality deficiencies, low operational efficiency, and two-year permit delays from the central government for grid construction (Junfeng et al., 2002; Han et al. 2009; Xingang et al. 2012; Luo et al. 2016; Zhao, Chang, and Chen 2016; Liao 2016; Sahu 2017). These issues have hampered China's wind power energy output and exports (Zhang et al. 2015; Sun et al. 2015).

Boettke (2002a) found that the failure to predict the fall of the Soviet Union was due to three reasons: (1) a disregard among economists

\footnotetext{
${ }^{1}$ As seen in Boettke's (2001) Calculation and Coordination, the degree of planning in the planned economy of the Soviet Union varied over the decades, and this is also the case for China, which tolerates different degrees of capitalism in different parts of its economic system. It has also been argued that the Soviet economy was never a planned economy but rather a form of military-state capitalist system (Polanyi 1957). A similar argument can be made about the Chinese economy. In the Chinese case presented in this paper, it is not a case of pure socialism but rather there are plans, government orders, and an environment in which traditional entrepreneurs find it difficult to thrive.

${ }^{2}$ E.g., the problematic housing market and a fast-increasing debt (see Liu 2018; Curran 2018).
} 
for evidence other than measurable statistics, (2) the elegance of the formal structure of central planning and the balancing of inputs and outputs, and (3) the preoccupation with aggregate measures of economic growth as opposed to detailed microeconomic analysis of the industrial structure. All, but especially the third reason, are an appropriate approach when investigating Chinese economic shortcomings.

Taking inspiration from Boettke's insight above, the purpose of this article is to synthesize the literature that has documented problems in Chinese wind power development and theoretically explain these problems. Identifying problems should be useful for policymakers in other countries that are considering a transition to large-scale renewable energy utilization. In a broader sense, the paper adds to the discussion of the sustainability of Chinese economic expansion in the long term.

A reader who is familiar with the Chinese wind energy sector and has read influential works, such as Joanna Lewis's 2012 book Green Innovation in China: China's Wind Power Industry and the Global Transition to a Low-Carbon Economy, would probably perceive that on an aggregate level everything is all right. In Lewis's book, as well as in most academic literature, the economic problems of Chinese energy are alluded to but never assembled and analyzed. In this article a less optimistic view of the state of China's wind power development is presented.

It should be noted that the United States and other countries also have different government interventions in the wind power market and that negative effects have been documented. For example, US policies in the 1980s caused problems similar to the ones observed in China (Keller and Negoita 2013). Later the United States policies focused on promoting research and development (R\&D) (Wiser and Millstein 2020). The German Energiewende (energy transition) and the Spanish solar bubble would be good cases for another paper, but this paper will focus on China since it is the largest producer at the moment and will probably be for some time to come.

The findings will be presented and followed by an analysis based on theoretical works by scholars of the Austrian school of economics which is utilized in two ways: firstly, in terms of its theoretical contributions regarding the role of entrepreneurship and its 
utilization of price signals, ${ }^{3}$ and, secondly, in terms of the planning debate, the use of knowledge in society, and the role of the market. Using Austrian economic theory as a starting point, it is found that both a planning problem and an entrepreneurial problem exist where governmental policies create misallocation of resources and a hampering of technological development.

The article is organized as follows: First, the Austrian theoretical background for the analysis of the wind power sector will be provided. Then, the historical context for China's wind power development will be described. Finally, the theoretical framework will be utilized to analyze problems in Chinese wind power development.

\section{THE LIMITATIONS OF PLANNING AND THE ENTREPRENEURIAL PROCESS}

A cartoon in the Soviet satirical journal Krokodil that was published in 1952 showcases the failure of the Soviet economic system with a worker and a bureaucrat depicted under an enormous two thousand-kilo nail. The worker asked who needed such a big nail and the bureaucrat answered: "the month's plan fulfilled" (Nove 1986, 94). The Soviet Union and its planned economy ended at the age of seventy-four years in 1991, which was a surprise for some, but not to a student of Hayek's (1937, 1945), Mises's (1920, 1949, n.d.) and Weber's (1922) contributions to the great planning debate in the 1920s through to the 1940s (see also Lavoie 1985a and 1985b).

Let us contrast the outcome of a market with that of a centrally planned arrangement. In a market, profit is a powerful signal. Profit informs producers that consumers value that use of those scarce resources as compared to other alternatives (in the case of profits) or that they do not value that use (in the case of losses). Before a

\footnotetext{
${ }^{3} \mathrm{~A}$ reviewer brought up merit order (describes the lowering of power prices at the electricity exchange due to an increased supply of renewable energies) effects and cannibalizing effects (loss in sales caused by a company's introduction of a new product) that might affect firms' behavior when it comes to adding new capacity. In a stable demand market this is an issue; however, the Chinese electricity consumption increased several hundred percent during the studied period and the renewable energy portion was rather small compared to the absolute growth in other energy sources.
} 
corrective process moves toward even an approximate equilibrium, changes in the market (individual preferences, the endowments of resources, and available technology) will distort any plan and make it irrelevant (Mises [1929] 2011; Kirzner 1982, 1999).

Hayek ([1968] 2002) remarked that an equilibrium was too much to hope for, since an equilibrium would presume that all facts are known and that the process of competition has thus ended, rather than that there could be temporary order. Several studies highlight how state planning, with the best of intentions, often fails (see Hayek [1935] 1956; and for a modern application to development and aid, see Boettke 1994; Leeson 2008; Coyne and Ryan 2009; Williamson 2010; Coyne 2013). The case against regulation and interventions in the market (even by well-meaning planners), is based on the insight that the market will never be close to an equilibrium state since there is an ongoing corrective process.

Even though the functioning of the bureaucracy has been more fleshed out by public choice scholars, the Austrians have made contributions to our understanding of how a state bureaucracy works. For example, Niskanen (1994) pointed to the fact that Mises (1944) is often credited as one of the first scholars to approach the problems of bureaucracy from an economic point of view.

Niskanen's and Mises's views of bureaucracy differ in significant ways. In Niskanen's view the bureaucracy is the result of the inability of the market to supply certain goods or services. A state bureaucracy compensates for the deficiencies of the market. According to Mises, bureaucracy appears because of government hindrances of the market process, but bureaucracy also makes economic calculation impossible (Carnis 2009). The Misesian view is more productive for the understanding of the Chinese case where the bureaucratic nature of the Chinese economy is a consequence of human action and design.

In Bureaucracy Mises contrasts different forms of economic organization and shows what happens when there is no profit motive. Mises argues that "[b]ureaucratic management is the method applied in the conduct of administrative affairs the result of which has no cash value on the market.... Bureaucratic management is management of affairs which cannot be checked by economic calculation" (1944, 47-48). If you do not have profits and losses 
as guide you must follow rigid rule systems. These rule systems will not allow for flexibility and will rather force the bureaucrat to compliance, whether the result make sense or not.

Constant feedback generates socially desirable outcomes without a central coordinator. Knowledge of the optimal use of scarce resources is not given ex ante but instead must be discovered through the process of individual choice (Mises 1920, 1949, n.d.; Hayek 1945). Hayek ([1968] 2002) and Buchanan (1982) also emphasized that market "data" emerge after people interact with each other. Before the participants enter the process, they do not know what their choices will be. Hence, some economics knowledge cannot be gathered by regulators and planers before the interactions take place.

A prerequisite for successful entrepreneurial action is guidance by relative price signals and the attraction of pure profit (which requires calculation through profit and loss accounting). The price system economizes information which economic decision-makers must process. A market system produces social intelligence that no one planner or group of planners could approximate (Boettke $2002 b$ ). In the setting of a functioning market economy, the entrepreneur will try to make a monetary profit, which, as described by Smith (1776), enriches the other participants in the economy. Without these important indicators, the economic actor is lost (Mises 1949). These indicators are the product of specific institutional configurations. Absent the institutional context of a private property market society, economic actors will still strive to achieve their goals as best they can (North 1990).

There are several views on what entrepreneurship constitutes. Kirzner's (1973) focuses on entrepreneurial alertness and the discovery of opportunities, where the entrepreneur is an actor responsible for creating and expanding businesses. The entrepreneurial process reveals previous errors, adjusts these errors, and thus improves the economy (Kirzner 1997).

Lavoie (1985a) extended Kirzner's work regarding the entrepreneurial market process and revisited the socialist calculation debate and the problems of centralized economic planning (1985a). In Lavoie (1985b) the knowledge problem critique of socialist central planning is extended to include even modest attempts at national 
economic planning, such as industrial policy, where attempts at planning did not function well.

The Schumpeterian view of the entrepreneur emphasizes the entrepreneur as a creator of new combinations of knowledge (Klein 2008). In Schumpeter's work ideas about an economy's creative response to changes in external conditions are highlighted (Schumpeter 1934, 1942, 1947). ${ }^{4}$ Entrepreneurs are present in all societies. Under the existing institutions of any society the entrepreneurs will act to better their position, e.g., money, promotions, or future advancement (Boettke and Coyne 2009; Redford 2020). Schumpeter's entrepreneur is essentially disruptive, destroying the preexisting state of equilibrium, while Kirzner's entrepreneur spots opportunities in a disequilibrium and moves the economy toward an equilibrium. In Kirzner (1999) it is argued that the two types of entrepreneurs are not that different, rather they complement each other.

The entrepreneurial process can be contrasted with the social discoordination and lack of economic calculation which necessarily follow any institutional coercion against entrepreneurial freedom. The contrast is an administrative-or centrally planned economy. In a centrally planned economy resources are allocated to fulfil production goals (Mises [1929] 2011; Hayek 1945). The production decisions are set by an administrator with limited information and its own preferences rather than consumer demand. Plans distort the discovery process that an entrepreneur typically provides. Without price as a market signal the planner must rely on alternative measures or disregard signals all together (Huerta de Soto [1992] 2010). Entrepreneurship produces the information necessary for economic calculation. It is impossible to use a theoretical foundation in order to coordinate society by systematically imposing coercive measures.

Institutions create rules which incentivize certain behaviors by changing the payoffs associated with different behaviors. Institutions hence influence the entrepreneur's actions and are instrumental to economic prosperity (e.g., Boettke and Coyne 2003, 2009). The factors that have been emphasized, by scholars adherent to the Austrian school, are: 1) well-defined and enforceable private

\footnotetext{
${ }^{4}$ There are of course more views on entrepreneurship (see, e.g., Leeson and Boettke 2009).
} 
property rights, 2) the rule of law, and 3) a moral code of behavior that legitimizes and recognizes these traditions. For example, Hayek (1937, 1945, 1948) and Mises's (1920, 1949, n.d.) property rights argument revolved around the information problem. Without private property, exchange is distorted. Without market competition, the discovery process is hampered (Hayek [1968] 2002).

Baumol (1990) made the important distinction between productive and unproductive entrepreneurship. Entrepreneurs are under some institutional settings incentivized to destroy societal economic value or perform unproductive entrepreneurship (Baumol 1996). Baumol emphasized that whether entrepreneurship is value adding to society or oriented toward rent seeking or organized crime depends on the relative payoffs.

\section{THE CONTEXT-CHINA'S HISTORICAL WIND POWER DEVELOPMENT}

There is an increasing interest in the transformation of the Chinese energy system, whose cumulative wind power capacity increase is the largest in the world (Zeng et al. 2015; Lam, Branstetter, and Azevedo 2017; Karltorp, Guo, and Sandén 2017; Sahu 2017). Global installed capacity in 2018 was 597 gigawatts (WWEA 2019). Globally, 52.5 gigawatts were added in 2018, constituting an annual growth rate of 9.1 percent, of which China added 21 gigawatts. The Chinese accumulated wind power capacity was 217 gigawatts in 2018 (WWEA 2019).

China's early period of wind power expansion was slow. In the 1970s, wind power projects were limited to small off-grid projects in remote areas (Liu, Gan, and Zhang 2002; Xu et al. 2010). Grid-connected wind power in China was achieved in 1985, when four 55-kilowatt Vestas turbines were imported from Denmark (Zhengming et al. [2006]). International agencies such as the World Bank, the United Nations Environment Programme (UNEP), and Asian Development Bank facilitated China's early buildup of renewable energy (Liu, Gan, and Zhang 2002).

By the end of 2004, accumulated installed wind capacity was 769 megawatts, ranking tenth in the world (Zhang, Andrews-Speed, and Zhao 2013). During China's "Eleventh Five-Year Plan" period 
(2006-10), installed capacity doubled for five consecutive years (Sun et al. 2015). Around 2012 China bypassed the USA as the country with most installed capacity (see figure 1). The installed capacity of a power system represents the maximum capacity that the system can produce under ideal conditions. A power plant with a one-megawatt installed capacity can, hence, produce at maximum one megawatt at any instance of time. Electricity generation, on the other hand, describes the amount of electricity that actually is produced during a specific period and is normally measured in kilowatt hours or megawatt hours.

\section{Figure 1. Installed wind power capacity in the US and China,} 2000-16

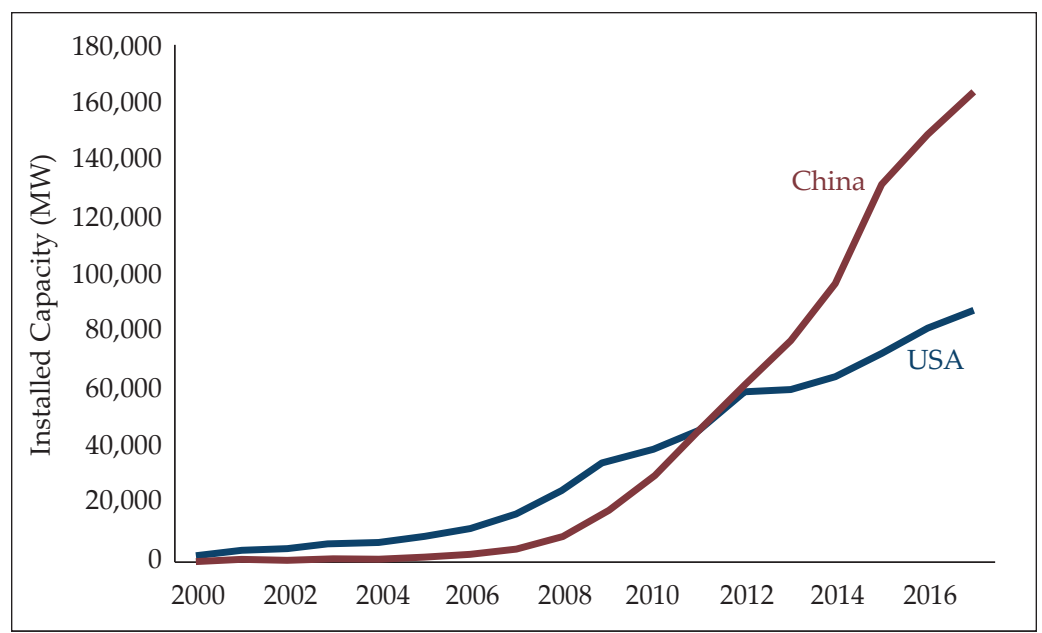

Source: Data from IRENA (2018).

However, when it comes to electricity generation the United States was for a long time significantly higher, even though the Chinese installed capacity was almost double-the electricity output was almost equal (See figure 2). 
Figure 2. Electricity generation from wind power in the US and China, 2000-17

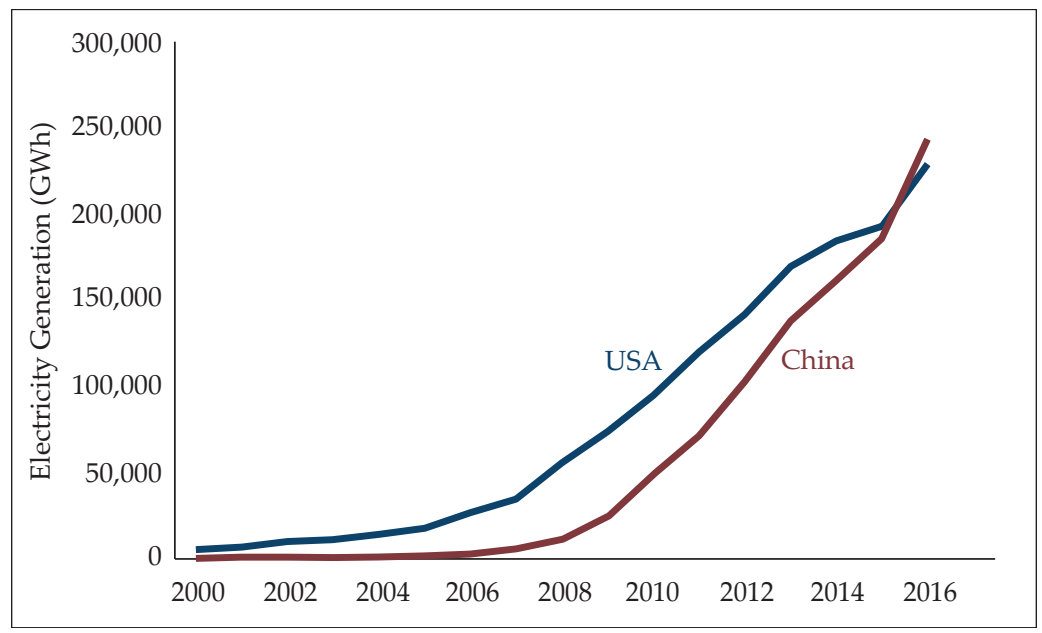

Source: Data from IRENA (2018).

\section{PROBLEMS AND CONSEQUENCES}

Several problems in Chinese wind power development have been identified and these downsides will be highlighted and discussed from a theoretical perspective. This synthesis of those problems is organized as follows: planning problems and knowledge problems; unproductive entrepreneurship; and bureaucracy and government policy.

\section{Planning Failures and Knowledge Problems}

The Chinese wind power industry has faced institutional, managerial, technological, and cultural obstacles. When analyzing undesirable policy results, an economist usually resolves to examine the incentive structure. So, what explains China's results? The short answer is that the results are in line with the incentives found in an economy where planning and bureaucracy dominate (see e.g., Mises 1944; Nove 1982; and Boettke 2001, 2002a). The existing incentives limit traditional entrepreneurship and have replaced it 
with institutional entrepreneurship, in which entrepreneurs must navigate the bureaucracy and engage in rent seeking (Mises 1944; Li, Feng, and Jiang, 2006; Huerta de Soto [1992] 2010).

Many of the problems in China's wind power development reside in political decision--making (Zhang, Andrews-Speed, and Zhao 2013; Huenteleret al. 2018). Governmental policies promoting installed capacity rather than actual utilization of wind resources have been a prevalent problem (Pengfei 2008; Li et al. 2018). For example, Chinese firms were mandated to construct a certain amount of wind power generation capacity. Given the requirement at hand, bureaucrats at state-owned enterprises constructed a specific generation capacity-without ensuring that electricity was actually generated.

The need to construct a certain amount of wind power leads to the sacrifice of quality as a selling point and to an intense price competition that hampers technological improvement and quality (Hayashi et al. 2018). Theoretically, competition should improve the quality of products. However, because quantity - not quality - is the factor for businesses to maximize and actors are spending someone else's money on someone else, an equilibrium of lower prices and increase sales through quality reductions can be expected. In the case of Chinese wind power, the result of this quality reduction is that the equipment cannot be integrated in a large-scale grid (Xingang et al. 2012; Luo et al. 2016).

Furthermore, foreign firms exited the market driven by quantity competition and a prerequisite in the Power Purchase agreements which stipulated that there should be 50 percent local content (later 70 percent) in the wind turbines. During the eleventh five-year plan (2006-10), plans were made to advance the domestic wind power system and its related components (Feng et al. 2015). While approximately 95 percent of the turbines installed in China until year 2000 were imported, the following decades saw a significant drop. In 2005, more than 70 percent of China's wind power equipment was imported; in 2008, only 28 percent; and by the end of 2013, domestic manufacturing levels had reached 94 percent (Junfeng, Pengfei, and Hu 2010; Liu et al. 2015; Zhang et al. 2015). In 2012 there were only two international firms (Gamesa and Vestas) among the top ten parts manufacturers 
in China, accounting for 3.8 percent and 3.2 percent of production, respectively (Feng et al. 2015).

The domestic production goal set in the eleventh five-year plan was fulfilled but created problems. Domestic production overcapacity caused further downward price pressure: in 2011, the manufacturing capacity was 30 gigawatts, but the annual demand was only 18 gigawatts (Li et al. 2012; Zhang et al. 2015). In 2013 the domestic new installed capacity was 16 gigawatts while only 0.7 gigawatts were exported, i.e., around 4 percent of domestic capacity (Liu et al. 2015).

The markets for advanced components such as bearings, converters and control systems were still dominated by international companies. The absence of domestic production capability generated a sizable supply-demand gap for core parts needed in turbines with a capacity exceeding one megawatt, and placed manufacturers at a technology import-absorption stage without key technologies of their own (Xingang et al. 2012). Before 2013 domestic Chinese turbine manufacturers were falling behind noticeably compared to international competitors, in cases where the Chinese companies had not mastered the construction of larger power plants (Liu et al. 2015).

Adam Smith, Ludwig von Mises, and F. A. Hayek all highlighted property rights as the roots of economic development. Property rights are lacking when the state mandates firms to construct unprofitable power plants. Smith's (1776) argument regarding property rights revolved around the incentives they created. Where property is privately owned, agents are residual claimants on the uses of their property and would not build power plants never meant to be operated. A state employee in a state-run firm who tries to follow state production requirements does not have the same profit motive.

The government policies that intervened in property rights, created a quality-price downward spiral which drew foreign firms out of the market since they could not compete at the low price levels (Klagge et al. 2012). Hence, an important source of know-how and technology transference was cut off. Paraphrasing Kirzner's (1985) observation; if one (China) only observes how many new plants are constructed and the generating capacity, one might miss "lightbulb moments" that could have made every wind plant more efficient. 
In China the single-minded focus on expansion of a good within a planned economy created a path toward a low quality equilibrium.

\section{Unproductive Entrepreneurship}

As Baumol (1990) pointed out, the entrepreneur can engage in productive and unproductive activities. Subsidies, price interventions and capacity goals have made the productive role of the classical entrepreneur absent under these Chinese institutional settings. In a market economy, it is illogical to construct a wind power plant absent grid connection. However, when the goal is to build as many power plants as possible, with the state and not the entrepreneur owning the company, the cheapest way to achieve the government's planned goal is to buy inferior products for inferior locations. Hence, as stated by Boettke and Coyne (2009), the institutions controlling the entrepreneur's behavior are instrumental to economic prosperity. Policies can affect the outcome, but even good policy can create unintended consequences under bad institutions (Rothbard [1970] 1977; Coyne and Moberg 2015; Evans 2016).

Wind power curtailment mainly refers to when a wind turbine must be shut down because of issues of safety, technology, and grid access management, and for other reasons. China has experienced extensive wind power curtailment, leading to a low power plant utilization rate (Sun et al. 2015; Fan et al. 2015; Zeng et al. 2015; Luo et al. 2016). The curtailment between the years 2010 and 2013 was estimated to be $3.9,10,20.8$, and 16.2 terawatt hours, respectively (Luo et al. 2016). The rapid installation of new wind turbine capacity without adequate maintenance and management technologies compromised operation safety (Feng et al. 2015). From a technological perspective, Lin et al. (2016) identified four reasons for the operating failures: lack of core technologies; inferior quality due to price competition; design standards and wind farm climate differences; and exterior factors, such as wind farm construction, power grids, and maintenance.

In 2007 the average full-load hours of Chinese wind turbines was 1,787, which was considerably lower than in Western countries such as the United Kingdom (2,628 hours), Australia (2,500 hours), and the United States (2,300 hours). In China, some 
turbines designed for two thousand full-load hours are currently in operation for only three hundred hours a year (Sahu 2017). The utilization fall due to curtailment was up to 15 percent between 2011 and 2015, rendering sizeable financial costs, equivalent to about half of the wind farms' revenues (Luo et al. 2016; Karltorp, Guo, and Sandén 2017). Bad wind turbine performance, such as when turbines without low-voltage capability ride through disconnect from the power system, creates potential safety risks in the power system. ${ }^{5}$ Disconnections lead to secondary shocks, which in turn can spill over into other parts of the system (Sahu 2017; Zeng et al. 2015).

The coerced focus on constructing power plants also led to some questionable location decisions. China's wind resourcerich regions are largely situated in the northern nonpopulated areas at the end of the power grid, where the grid structure is unsuitable for large-scale wind power (Han et al. 2009). Energy demand is concentrated in the south and around the coast, where manufacturing and a large portion of the population are situated. Placing a wind power plant over three thousand kilometers away from the main demand would in any system lead to significant power losses. Grid connection capacity has in some years lagged installed capacity by more than 30 percent. The result has been that power generation has exceeded the grid's capacity, leading to abandonment and grid instability (Zhe 2011; Sun et al. 2015; Fan et al. 2015; Zeng et al. 2015; Zhang et al. 2017). ${ }^{6}$

Another field negatively affected by wind power policy is technological development. Chinese inventors have been granted few international but numerous domestic patents. Beginning around the year 2000, granted domestic patents flourished. According to Lei et al. (2013) and Li (2012), governmental programs aimed at increasing the number of patents explain the surge. Chinese

\footnotetext{
${ }^{5}$ The capability of electric generators to stay connected if lower electric network voltage occurs for a short period. Without this capability a chain reaction might start where more generators are disconnected.

${ }^{6}$ Grid expansion is costly for power companies, and upgrading the power grid can be even more costly. Even though the concession project policies state that companies shall construct transmission lines to the wind farms, there are potential loopholes regarding when the construction has to be finished or the quality of the transmission line (Han et al. 2009).
} 
companies were incentivized to seek local patents. Gosens and $\mathrm{Lu}$ $(2013,2014)$ also noticed that the number of granted patents were an evaluation criterion for many researchers and administrators. Promotions depended on goal fulfilment, and a certain number of patents was a government goal (Li 2012; Lam et al. 2017). ${ }^{7}$

In terms of wind power innovation, however, China had limited international success (Lam, Branstetter, and Azevedo 2017). Chinese wind turbine manufacturers secured few international patents, and several major manufacturers were unable to patent their technologies. For example, granted patent applications to the European Patent Office (EPO) originating in China were low (between 1980 and 2014). Even if a firm do not intend to produce on a certain market it is beneficial to patent breakthroughs to license the usage to other firms. Home country bias in patenting should be expected but it is remarkable that so many big industrial manufacturing firms that are engaged in a fast-developing technology do not patent.

The two major Chinese firms that tried to patent-Envision and XEMC-lodged thirty-eight and nineteen EPO applications, respectively. The two firms were granted two and six patents. The firm Sinovel submitted twenty-one patent applications to the EPO; of these all but one was either subsequently withdrawn by Sinovel or rejected by the EPO. At the EPO the average application has a fifty percent success rate (see Grafström, 2017). Among the top ten Chinese wind power manufacturing firms, seven obtained no EPO patents, and five of them have no recorded EPO applications. The success and application rates were similar at the USPTO.

Only observing a single patent office (such as a country's home office) is not an optimal method for comparing the countries with the most patents in the wind sector, since the local offices can have criteria with differing degrees of strictness. In figure 3 the distribution of wind power patents among these countries when only considering patents approved at one patent office is displayed (see the appendix for each country's total patents):

${ }^{7}$ The Chinese legal system also had problems with distinguishing real innovations from false innovations. Hence, there was a large number of "junk" patents (Lam, Branstetter, and Azevedo 2017). 
Figure 3. Proportion of patents awarded by one office or more

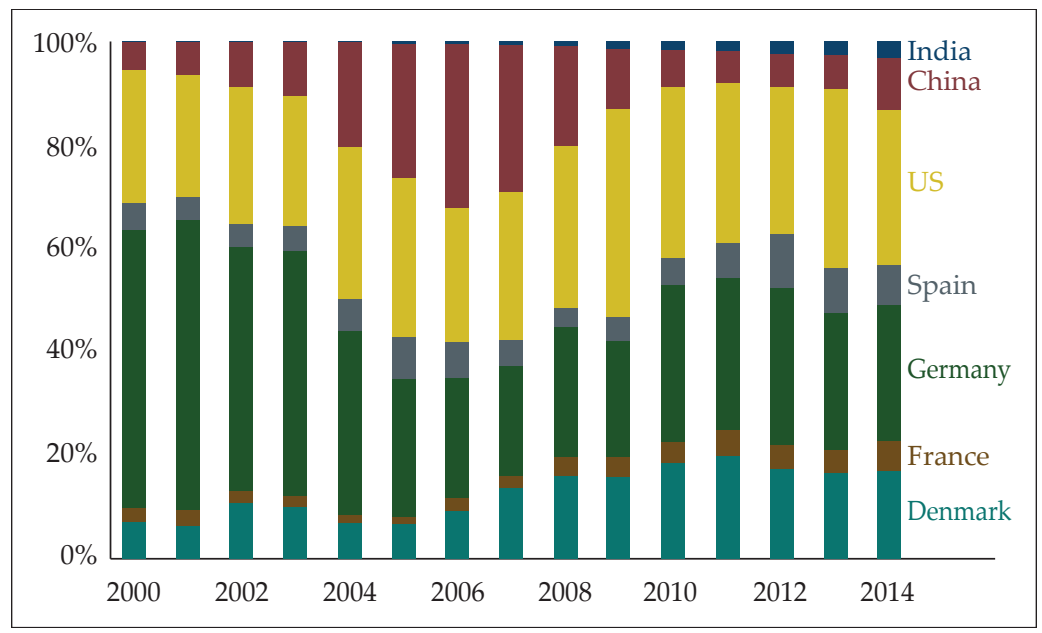

Source: Data from OECD.Stat (Patents - Technology Development; accessed [10 05, 2018]), [https://stats.oecd.org/].

The aggregate Chinese patent approval was high around 2006, but only if data from one patent office is considered. If the criteria are changed to require that the patent be approved by more than one office (an indicator of a higher-quality patent), as in figure 4, then the Chinese patents are absent. 
Figure 4. Proportion of patents awarded by four or more patent offices

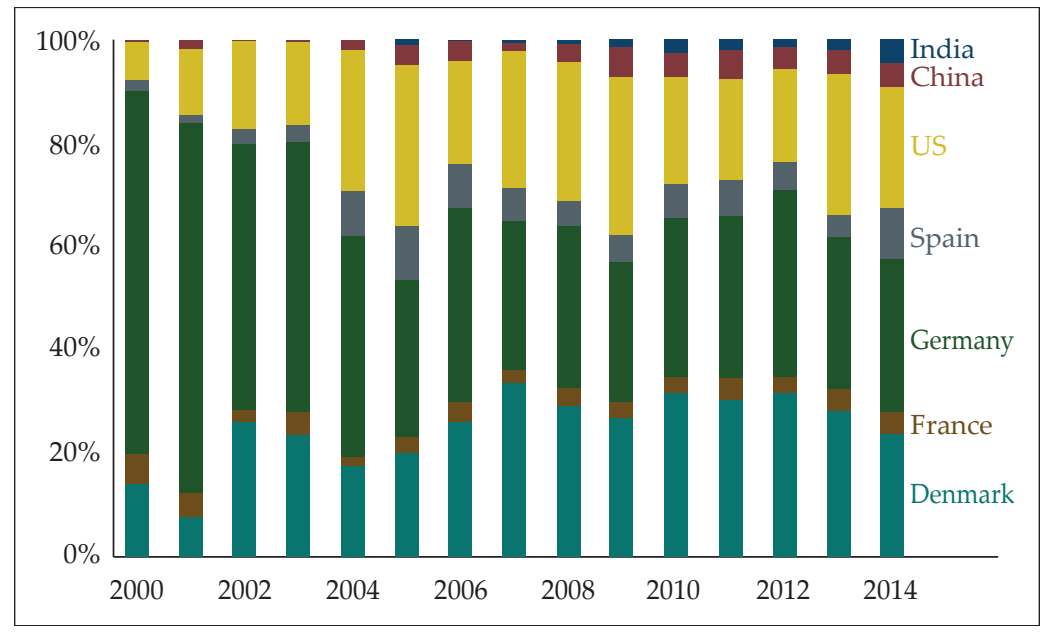

Source: Data from OECD.Stat (Patents Technology Development; accessed [10 05, 2018]), [https://stats.oecd.org/].

It is likely that it was easier to obtain a patent in China in the early 2000s and that Chinese patents were thus of lower quality, making a side-by-side comparison unproductive. Before 2009 Chinese patent examiners limited their search reports to domestic prior art, thus not considering global novelty (Cass 2009).

From a theoretical standpoint, both a planning problem and an entrepreneurial problem are evident. Policies (as, for example, requiring patents to be secured) trying to direct production and investments is often counterproductive. Drawing on insights from Kirzner (1982), it is unsurprising that attempts at technological development by direct regulation and interventions are based on erroneous information that obstructs or distorts the market's own complicated discovery process (Rothbard [1970] 1977; Huerta de Soto [1992] 2010). The entrepreneurial process incentivizes entrepreneurs to reveal previous errors and to adjust behavior to correct those errors (Kirzner 1997). When patenting becomes a numbers game (paired with a demand for as low a price as possible, with a disregard for quality), growth can be expected in what is countedin this case patents. 
The Schumpeterian creative destruction process also becomes a dangerous activity in a planned economy. There is a risk that the process will disrupt the plan, and no resources can be allocated to a previously unknown venture. The destruction can also threaten the power of those who might prefer the status quo. Hence, whereas the entrepreneur would struggle against competition in a market economy, he will face a political power struggle in a planned economy.

Following Hayek's “The Use of Knowledge in Society" (1945) it is evident that any central plan will face obstacles. A centrally planned wind power program in many instances will not match the efficiency of the market. The incentives, knowledge, and imagination of a single planner are only a small fraction of the total sum of knowledge in society.

\section{Bureaucracy and Government Policy}

As Mises $(1983,53)$ observed, the allocation of resources by bureaucracy is made through obedience to rules. When making decisions based on rules, without price signals, consumer satisfaction or production toward a low cost cannot be achieved. The system of profit and loss plays little role in the bureaucratic machinery, and to the extent that it does play a role, the highest value is placed on the bureaucratic administration's rule-following ability. Hence, we can expect a t neglect of entrepreneurship and prices and costs where rules and regulations determine the product to be supplied, its characteristics, its price, and the method of production (Carnis 2009).

The Chinese wind power sector was under the studied period (1980-2016) profoundly regulated by administrative practices and planning. Some policies were counterproductive due to several competing/uncoordinated governmental entities (Lema and Ruby 2007). For example, Liao (2016) examined seventy-two wind energy policies issued between 1995-2014 and found more than twenty actors who independently or jointly issued policies. The issuers of policy were predominantly agencies that controlled key economic and administrative resources-not the one that oversaw wind power. The governmental agencies could not tap into the localized knowledge or predict the direction of a fast-developing 
technology. Hence, the agencies produced policies that hindered technological development.

In 1994, one of China's earliest wind power-specific policies was introduced. The Ministry of Electric Power (MOEP) decided that installed wind power capacity should increase a hundredfold, from about ten megawatts in 1993 to one thousand megawatts in 2000. The government's target was not reached, stopping at 350 megawatts. To support the government production target, power companies were obliged to buy (or produce) electricity from wind power, and they introduced a price guarantee of 15 percent above construction cost to developers (Lema and Ruby 2007). The policy measures failed, since they did not achieve legal status, meaning that noncompliance was not penalized. Noncompliance was extensive, which was not surprising considering that wind energy was significantly more expensive than coal power (Lema and Ruby 2007; Karltorp, Guo, and Sandén 2017).

Another policy-related example is revealed in the wind farm approval process. Government contract projects appeared in the early 1980s, while the first concession project was carried out in 2003 after a new concession model was established (Han et al. 2009). Approval of contract projects worked as follows: wind power companies presented large (over fifty megawatts) project proposals to the National Development and Reform Commission (NDRC) and smaller (under fifty megawatts) proposals to local administrations such as the Inner Mongolia Development and Reform Commission (IMDRC), whose decisions did not require approval from the NDRC.

The division of the approval process by project size in 2003 was intended to reduce bureaucratic delays. Previously every new project required approval by the NDRC, making the application process for wind power projects complex and time consuming. Since provincial governments could now approve projects below fifty megawatts, a substantial number of wind farms became 49.5 megawatts in size. These smaller local installations were not coordinated in terms of the development of grids, rendering grid problems (Lema and Ruby 2007; Zhang, Andrews-Speed, and Zhao 2013; Karltorp, Guo, and Sandén 2017).

The 2003 concession model opened, and to some extent formed, a market-but the new planned organization had weaknesses 
(Lema and Ruby 2007). The utilities/firms that offered the best price per kilowatt hour won the concessions and consequently the right to construct wind power plants and produce electricity on the concession sites. The winner was guaranteed a fixed price for the first thirty thousand full-load hours (these were power purchase agreements, PPA). After the initial thirty-thousand full-load hours and until the end of the concession period, electricity would be sold at a uniform on-grid price. The concession model had some unintended and in hindsight obvious disadvantages. Some bidders had incentives to intentionally underestimate operating costs to promise a lower price compared to other bidders.

The power companies in China were obligated to have a certain amount of generation capacity from renewable energy sources; the renewable energy portfolio standards were due to the Renewable Energy Law of 2006 (Gosens and Lu 2013). The combination of the renewable portfolio standard and the concession program initiated a steep fall in the prices of the winning bids (between 30 and 50 percent), since the firms were obligated to have the renewable output. The companies made unprofitable bids using the cash flow from other business areas to sustain unprofitable projects, but the governmental goals were fulfilled. Another price distortion came from the Chinese government's attempt to support construction of power plants by introducing a price guarantee of 15 percent above construction cost, which incentivized developers to construct otherwise unprofitable plants (Lema and Ruby 2007).

Another problem can be observed in the bureaucratic nature of a Chinese renewable energy price subsidy scheme which caused financial constraint problems in several sectors (Liu et al. 2015; Karltorp, Guo, and Sandén 2017). The electricity end users were obliged to pay a surcharge for renewable electricity. The payment went into a fund under the Ministry of Finance, which redistributed the money to the provincial finance bureaus. The provincial finance bureaus distributed the money to local utility companies based on their renewable energy production. The companies had to wait two to three years for the payments, which was problematic considering that the subsidies were up to half the selling price of electricity (Sahu 2017). The firms in turn had problems paying the turbine manufacturers, who in turn could not pay the component providers. 
It is problematic that pricing for both wholesale and retail power remains under the control of the central government, since the central government has failed to deliver incentives for flexibility for generators and end users. The influence of provincial governments over the power system impedes interprovincial electricity trading (Pollitt et al. 2017). For example, local governments have repeatedly intervened in direct electricity trades, reducing energy prices to stimulate their local economies, even though that is not beneficial for the power system (Zhang, Andrews-Speed, and Li 2018).

The application of administrative rather than market mechanisms has been a major hurdle to a well-functioning Chinese energy system (Depuy 2015). Hence, without proper exchange no proper market prices will materialize. As noted by, for example, Mises (1949), price signals direct the entrepreneurs. Without these important indicators, the economic actor is lost. Hayek $(1937,1945)$ building on Mises, described the information-carrying capacity of market prices, which reveal value and the relative scarcity of resources for consumers and producers.

The problems that have been revealed here should come as no surprise since the Chinese political actors do not operate on a market, but rather in a planned economy with traces of a market. In a market economy, political actions (that are market compatible) can moderately distort market outcomes without modifying the modus operandi of the market (Mises 1944). In contrast, political actions that are noncompatible with market processes, especially in a nonmarket setting, produce an entangled political economy (Smith, Wagner, and Yandle 2010).

\section{IMPLICATIONS}

China's policies and regulations between 1980 and 2016 caused problems for a renewable energy transition situation. There were problems with management, strategies, programs, and policies, which were sorted and separated under numerous departments of the Chinese central and local governments. From an economic theoretical perspective, a a strong market structure would provide practical solutions to some of these challenges.

The findings in this paper have several implications. First, as in the 1920s, the 2020s could possibly see a great planning debate because 
of the perceived success of China's state-run five-year plans. In this paper, the wind power industry has been identified as revealing limitations to planning. To pass a comprehensive judgment on the Chinese economy more sectors must be investigated, following Boettke's insight that aggregates might be misleading and that answers hide at the micro level.

Second, there are applications for the coming global energy system transition. Policymakers should use market incentives or else their countries risk experiencing problems like China's. The observed Chinese power sector was profoundly regulated by administrative practices. Planning was likely the underlying institutional reason for the challenges that have been described.

Third, policymakers should acknowledge incentive problems. When any government set a command-and-control target for new installed capacity, the state power companies delivered to target. For example, the goal of increasing power plant capacity (with mandatory portfolios) led to construction (i.e., generation capacity) but not necessarily more generation of energy. The incentives in China promoted construction-regardless of whether the construction could be connected to a grid or was economically profitable. When a manager is evaluated based on how well he achieves the planned goal, he will optimize his effort to reach the goal, disregarding downsides such as the fact that the new power plants that will not be connected to a grid.

The findings have a last implication for other countries as a guide for what not to do. A policymaker should assume that they do not have enough information to create a detail-oriented approach to reducing carbon emissions for the whole economy.

A last reflection, going back to Boettke (2002a, 10):

Unfortunately, most individuals in these economies wake up every day and go to work at the wrong job, in a factory that is in the wrong place, to produce the wrong goods. Many of the firms actually contribute "negative value added", that is, the value of the inputs in the production process is greater than the market value of the output that is produced. This is the legacy of decades of attempted central administration of the economy.

The Chinese economy will probably become older than the Soviet economy managed to, but there should be caution against saying 
that "[ $t$ ]he Chinese economy outpaces the West" as in the infamous Foreign Affairs article from 1953.

\section{REFERENCES}

Baumol, William J. 1990. "Entrepreneurship: Productive, Unproductive and Destructive." Journal of Political Economy 98, no. 5: 893-921.

_. 1996. “Entrepreneurship: Productive, Unproductive, and Destructive." Journal of Business Venturing 11, no. 1, 3-22.

Boettke, Peter J., ed. 1994. Collapse of Development Planning. New York: New York University Press.

- 2001. Calculation and Coordination: Essays on Socialism and Transitional Political Economy. London: Routledge.

—. 2002a. Why Perestroika Failed: The Politics and Economics of Socialist Transformation. London: Routledge.

— . 2002b. "Information and Knowledge: Austrian Economics in Search of Its Uniqueness." Review of Austrian Economics 15, no. 4: 263-74.

Boettke, Peter J., and Christopher J. Coyne. 2003. "Entrepreneurship and Development: Cause or Consequence?" In Austrian Economics and Entrepreneurial Studies, edited by Roger Koppl, 67-87. Vol. 6 of Advances in Austrian Economics, edited by Roger Koppl, Jack Birner, and Peter Kurrild-Kiltgaard. Bingley, U.K.: Emerald Group Publishing.

— . 2009. "Context Matters: Institutions and Entrepreneurship." Foundations and Trends in Entrepreneurship 5, no. 3: 135-209.

Buchanan, James M. 1982. “Order Defined in the Process of Its Emergence." Literature of Liberty 5, no. 5: 7-58.

Carnis, Laurent A. H. 2009. The Economic Theory of Bureaucracy: Insights from the Niskanian Model and the Misesian Approach." Quarterly Journal of Austrian Economics 12, no. 3: 57-78.

Cass, Ronald A. 2009. "Patent Reform with Chinese Characteristics." Wall Street Journal, Feb. 10, 2009. http://online.wsj.com/news/articles/ SB123419814824764201.

Curran, Enda. 2018. “China's Debt Bomb." Bloomberg, updated Sept. 17, 2018. https://www.bloomberg.com/quicktake/chinas-debt-bomb. 
Coyne, Christopher J. 2013. Doing Bad by Doing Good: Why Humanitarian Action Fails. Stanford, Calif.: Stanford University Press.

Coyne, Christopher J., and Matt E. Ryan. 2009. "With Friends Like These, Who Needs Enemies? Aiding the World's Worst Dictators." Independent Review 14, no. 1: 26-44.

Coyne, Christopher J., and Lotta Moberg. 2015. "The Political Economy of State-Provided Targeted Benefits." Review of Austrian Economics 28, no. 3: 337-56.

Depuy, Max, David Crossley, Fritz Kahrl, and Kevin Porter. 2015. Low-Carbon Power Sector Regulations: Options for China. N.p.: RAP. http://suo.im/3Gc2OC.

Evans, Anthony J. 2016. "The Unintended Consequences of Easy Money: How Access to Finance Impedes Entrepreneurship." Review of Austrian Economics 29, no. 3: 233-52.

Fan, Xiao-chao, Wei-qing Wang, Rui-jing Shi, and Feng-ting Li. 2015. "Analysis and Countermeasures of Wind Power Curtailment in China." Renewable and Sustainable Energy Reviews 52: 1429-36.

Feng, Yi, Heyun Lin, S. L. Ho, Jianhu Yan, Jianning Dong, Shuhua Fang, and Yunkai Huang. 2015. "Overview of Wind Power Generation in China: Status and Development." Renewable and Sustainable Energy Reviews 50: 847-58.

Gosens, Jorrit, and Yonglong Lu. 2014. "Prospects for Global Market Expansion of China's Wind Turbine Manufacturing Industry." Energy Policy 67: 301-18.

_ 2013. From Lagging to Leading? Technological Innovation Systems in Emerging Economies and the Case of Chinese Wind Power." Energy Policy 60: 234-50.

Grafström, Jonas. 2017. Technological Change in the Renewable Energy Sector: Essays on Knowledge Spillovers and Convergence. PhD diss, Luleå University of Technology.

Han, Jingyi, Arthur P. J. Mol, Yonglong Lu, and Lei Zhang. 2009. “Onshore Wind Power Development in China: Challenges behind a Successful Story." Energy Policy 37, no. 8: 2941-51. 
Hayashi, Daisuke, Joern Huenteler, and Joanna I. Lewis. 2018. “Gone with the Wind: A Learning Curve Analysis of China's Wind Power Industry. Energy Policy 120: 38-51.

—_. (1935) 1956. Collectivist Economic Planning: Critical Studies on the Possibilities of Socialism. London: Routledge and Kegan Paul.

Hayek, F. A. von. 1937. “Economics and Knowledge." Economica, n.s., 4, no. 13 : 33-54.

— 1945. "The Use of Knowledge in Society." American Economic Review 35, no. 4: 519-30.

—. 1948. "'Free' Enterprise and Competitive Order." In Individualism and Economic Order, 107-18. Chicago: University of Chicago Press.

_ _ (1968) 2002. “Competition as a Discovery Procedure." Translated by Marcellus S. Snow. Quarterly Journal of Austrian Economics 5, no. 3: 9-23.

Huenteler, Joern, Tian Tang, Gabriel Chan, and Laura Diaz Anadon. 2018. "Why Is China's Wind Power Generation Not Living up to Its Potential?" Environmental Research Letters 13, no. 4, article no. 044001.

Huerta de Soto, Jesús. (1992) 2010. Socialism, Economic Calculation and Entrepreneurship. Translated by Melinda Stroup. Cheltenham, U.K.: Edward Elgar.

IRENA. 2018. Renewable Energy Statistics 2018. Abu Dhabi, U.A.E.: International Renewable Energy Agency.

Junfeng, Li, Zhu Li, Hu Runqing, Zhang Zhengmin, Shi Jingli, and Song Yangin. 2002. "Policy Analysis of the Barriers to Renewable Energy Development in the People's Republic of China." Energy for Sustainable Development 6, no 3: 11-20.

Junfeng, Li, Shi Pengfei, and Gao Hu. 2010. China Wind Power Outlook 2010. Chinese Renewable Energy Industries Association, Greenpeace, the Global Wind Energy Council. N.p.

Karltorp, Kersti, Siping Guo, and Björn A. Sandén. 2017. “Handling Financial Resource Mobilisation in Technological Innovation Systems - the case of Chinese Wind Power." Journal of Cleaner Production, 142, no. 4: 3872-82.

Klagge, Britta, Zhigao Liu, and Pedro Campos Silva. 2012. "Constructing China's Wind Energy Innovation System.” Energy Policy 50: 370-82. 
Keller, Matthew R., and Marian Negoita. 2013. "Correcting Network Failures: The Evolution of US Innovation Policy in the Wind and Advanced Battery Industries." Competition and Change 17, no. 4:319-38.

Kirzner, Israel M. 1973. Competition and Entrepreneurship. Chicago: University of Chicago Press.

- 1982. Competition, Regulation, and the Market Process: An "Austrian" Perspective. Policy Analysis no. 18. Washington, D.C.: Cato Institute.

- 1985. Discovery and the Capitalist Process. Chicago: University of Chicago Press.

_. 1997. "Entrepreneurial Discovery and the Competitive Market Process: An Austrian Approach." Journal of Economic Literature 35, no. 1: 60-85.

_. 1999. "Creativity and/or Alertness: A Reconsideration of the Schumpeterian Entrepreneur." Review of Austrian Economics 11, nos. 1-2: 5-17.

Klein, Peter G. 2008. “Opportunity Discovery, Entrepreneurial Action, and Economic Organization." Strategic Entrepreneurship Journal 2, no. 3: 175-90.

Lam, Long T., Lee Branstetter, and Inês M. L. Azevedo. 2017. “China's Wind Industry: Leading in Deployment, Lagging in Innovation." Energy Policy 106: 588-99.

Lavoie, Don. 1985a. Rivalry and Central Planning: The Socialist Calculation Debate Reconsidered. New York: Cambridge University Press. . 1985b. National Economic Planning: What Is Left? Cambridge, Mass.: Ballinger Publishing.

Lema, Adrian, and Kristian Ruby. 2007. “Between Fragmented Authoritarianism and Policy Coordination: Creating a Chinese Market for Wind Energy." Energy Policy 35, no. 7: 3879-90.

Leeson, Peter T. 2008. “Escaping Poverty: Foreign Aid, Private Property, and Economic Development." Journal of Private Enterprise 23, no. 2: 39-64.

Leeson, Peter T., and Peter J. Boettke. 2009. “Two-Tiered Entrepreneurship and Economic Development." International Review of Law and Economics 29: 252-59.

Levy, David M., and Sandra J. Peart. 2011. "Soviet Growth and American Textbooks: An Endogenous Past." Journal of Economic Behavior and Organization 78, nos. 1-2: 110-25. 
Lewis, Joanna I. 2012. Green Innovation in China: China's Wind Power Industry and the Global Transition to a Low-Carbon Economy. New York: Columbia University Press.

Li, David Daokui, Junxin Feng, and Hongping Jiang. 2006. "Institutional Entrepreneurs." American Economic Review 96, no. 2: 358-62.

Li, Lingyue, Xiaoqing Ren, Yanli Yang, Peidong Zhang, and Xiao Chen. 2018. "Analysis and Recommendations for Onshore Wind Power Policies in China." Renewable and Sustainable Energy Reviews 82: 156-67.

Li, Xibao. 2012. "Behind the Recent Surge of Chinese Patenting: An Institutional View." Research. Policy 41, no 1: 236-49.

Liao, Zhongju. 2016. "The Evolution of Wind Energy Policies in China (1995-2014): An Analysis Based on Policy Instruments." Renewable and Sustainable Energy Reviews 56: 464-72.

Liu, Bonnie. 2018. "Home-Owners or Home-'Slaves': China's Housing Market Frustrates Many." Harvard College Economics Review, 2018.

Liu, Wen-Qiang, Lin Gan, and Xi-Liang Zhang. 2002. "Cost-Competitive Incentives for Wind Energy Development in China: Institutional Dynamics and Policy Changes." Energy Policy 30, no. 9: 753-65.

Liu, Yuanxin, Lingzhi Ren, Yanbin Li, and Xin-gang Zhao. 2015. "The Industrial Performance of Wind Power Industry in China." Renewable and Sustainable Energy Reviews 43: 644-55.

Luo, Guo-liang, Yan-ling Li, Wen-jun Tang, and Xiao Wei. 2016. “Wind Curtailment of China's Wind Power Operation: Evolution, Causes and Solutions." Renewable and Sustainable Energy Reviews 53: 1190-201.

Mises, Ludwig von. 1920. “Die Wirtschaftsrechnung im sozialistischen Gemeinwesen." Archiv für Sozialwissenschaft und Sozialpolitik 47, no. 1: 86-121.

. (1929) 2011 Critique of Interventionism. Translated by Hans F. Sennholz. Auburn, Ala.: Ludwig von Mises Institute.

—. 1944. Bureaucracy. New Haven, Conn.: Yale University Press.

—. 1949. Human Action: A Treatise on Economics. Chicago: Henry Regnery.

- 2007. Theory and History: An Interpretation of Social and Economic Evolution. Auburn, Ala.: Ludwig von Mises Institute. 
. n.d. Planned Chaos. Auburn, Ala.: Ludwig von Mises Institute.

Niskanen, William A., Jr. 1994. Bureaucracy and Public Economics, Aldershot, U.K.: Edward Elgar.

North, Douglass C. 1990. Institutions, Institutional Change and Economic Performance. Cambridge: Cambridge University Press.

Nove, Alec. 1986. The Soviet Economic System. 2d ed Boston: Allen and Unwin.

Pengfei, S. 2008. "Booming Wind Power Market and Industry in China." Paper presented at the 7th World Wind Energy Conference, Kingston, Ont., June 24-26, 2008.

Pollitt, Michael G., Chung-Han Yang, and Hao Chen. 2017. "Reforming the Chinese Electricity Supply Sector: Lessons from International Experience." Cambridge Working Papers Economics 1713, March 20.

Polanyi, Michael. 1957. "The Foolishness of History: November, 1917November, 1957." Encounter November 1957, 33-37.

Redford, Audrey. 2020. "Property Rights, Entrepreneurship, and Economic Development." Review of Austrian Economics 33: 139-61.

Rothbard, Murray N. (1970) 1977. Power and Market: Government and the Economy. Menlo Park, Calif.: Institute for Humane Studies.

Sahu, Bikash Kumar. 2017. "Wind Energy Developments and Policies in China: A Short Review." Renewable and Sustainable Energy Reviews 18, no. 1: 1393-405.

Schumpeter, Joseph A. (1934). The Theory of Economic Development: An Inquiry into Profits, Capital, Credit, Interest, and the Business Cycle. Translated by Redvers Opie. New Brunswick, N.J.: Transaction Publishers.

—. 1942. Capitalism, Socialism, and Democracy. New York: Harper.

- 1947. "The Creative Responses in Economic History." Journal of Economic History 7, no. 2: 149-59.

Smith, Adam. 1776. An Inquiry Into The Nature and Causes Of The Wealth Of Nations. 2 vols. London: Printed for W. Strahan and T. Cadell.

Smith, Adam, Richard E. Wagner, and Bruce Yandle. 2011. "A Theory of Entangled Political Economy, with Application to TARP and NRA." Public Choice 148, nos. 1-2: 45-66. 
Sun, Shengpeng, Fengliang Liu, Song Xue, Ming Zeng, and Fanxiao Zeng. 2015. "Review on Wind Power Development in China: Current Situation and Improvement Strategies to Realize Future Development." Renewable and Sustainable Energy Reviews 45: 589-99.

Weber, Max. (1922) 1978. Economy and Society: An Outline of Interpretive Sociology. Edited by Guenther Roth and Claus Wittich. Berkeley, Calif.: University of California Press.

Wiles, Peter. 1953. "The Soviet Economy Outpaces the West." Foreign Affairs 31, no. 4: 566-80.

Williamson, Claudia R. 2010. "Exploring the Failure of Foreign Aid: The Role of Incentives and Information." Review of Austrian Economics 23, no. 1: 17-33.

Wiser, Ryan, and Dev Millstein. 2020. "Evaluating the Economic Return to Public Wind Energy Research and Development in the United States." Applied Energy 261: article no. 114449.

WWEA. 2019. “Wind Power Capacity Worldwide Reaches 597 GW, 50,1 GW added in 2018." Press release, Feb. 25, 2019, updated June 4, 2019. https://wwindea.org/wind-power-capacity-worldwide-reaches-600gw-539-gw-added-in-2018/.

Xingang, Zhao, Wang Jieyu, Liu Xiaomeng, and Liu Pingkuo. 2012. "China's Wind, Biomass and Solar Power Generation: What the Situation Tells Us?" Renewable and Sustainable Energy Reviews 16, no. 8: 6173-82.

Xu, Jianzhong, Dexin He, and Xiaolu Zhao. 2010. "Status and Prospects of Chinese Wind Energy." Energy 35, no. 11: 4439-44.

Zeng, Ming, Jinhui Duan, Liang Wang, Yingjie Zhang, and Song Xue. 2015. "Orderly Grid Connection of Renewable Energy Generation in China: Management Mode, Existing Problems and Solutions." Renewable and Sustainable Energy Reviews 41: 14-28.

Zhang, Dahai, Jiaqi Wang, Yonggang Lin, Yulin Si, Can Huang, Jing Yang, Bin Huang, and Wei Li. 2017. "Present Situation and Future Prospect of Renewable Energy in China." Renewable and Sustainable Energy Reviews 76: 865-71.

Zhang, Huiming, Yu Zheng, Dequn Zhou, and Xingle Long. 2018. "Selection of Key Technology Policies for Chinese Offshore Wind Power: A Perspective on Patent Maps." Marine Policy 93: 47-53. 
Zhang, Sufang, Philip Andrews-Speed, and Sitao Li. 2018. "To What Extent Will China's Ongoing Electricity Market Reforms Assist the Integration of Renewable Energy?" Energy Policy 114: 165-72.

Zhang, Sufang, Philip Andrews-Speed, and Xiaoli Zhao. 2013. "Political and Institutional Analysis of the Successes and Failures of China's Wind Power Policy." Energy Policy 56: 331-40.

Zhang, Sufang, Wei Wang, Lu Wang, and Xiaoli Zhao. 2015. "Review of China's Wind Power Firms' Internationalization: Status Quo, Determinants, Prospects and Policy Implications." Renewable and Sustainable Energy Reviews 43: 1333-42.

Zhao, Zhen-Yu, Rui-Dong Chang, and Yu-Long Chen. 2016. "What Hinders the Further Development of Wind Power in China? - a Socio-technical Barrier Study." Energy Policy 88: 465-76.

Zhe, S., 2011. "China World's No.1 in Installed Wind Power Capacity." Global Times, Jan. 14, 2011. https://www.globaltimes.cn/content/612556.shtml.

Zhengming, Zhang, Wang Qingyi, Zhuang Xing, Jan Hamrin, and Seth Baruch. [2006]. Renewable Energy Development in China: The Potential and the Challenges. Edited by the Center for Resource Solutions. N.p.: Center for Resource Solutions. https:/www.efchina.org/Attachments/ Report/reports-efchina-20061026-55-zh/China_RE_Report_EN.pdf/ at_download/file. 


\section{APPENDIX}

Table 1. Absolute number of patents registered at one or more patent offices

\begin{tabular}{|l|l|l|l|l|l|l|l|}
\hline Year & China & Germany & USA & Denmark & Spain & France & India \\
\hline 2000 & 12 & 121 & 59 & 15 & 11 & 6 & 0 \\
\hline 2009 & 174 & 361 & 652 & 247 & 70 & 59 & 26 \\
\hline 2014 & 96 & 270 & 313 & 171 & 74 & 61 & 35 \\
\hline
\end{tabular}

Rounded to the nearest whole number. Source: Data from OECD.Stat (Patents Technology Development); accessed [10 05, 2018]), [https://stats.oecd.org/].

\section{Table 2. Absolute number of patents registered at four or more} patent offices

\begin{tabular}{|l|l|l|l|l|l|l|l|}
\hline Year & China & Germany & USA & Denmark & Spain & France & India \\
\hline 2000 & 0 & 36 & 4 & 7 & 1 & 3 & 0 \\
\hline 2009 & 12 & 123 & 108 & 122 & 22 & 13 & 6 \\
\hline 2014 & 8 & 60 & 48 & 48 & 19 & 9 & 9 \\
\hline
\end{tabular}

Rounded to the nearest whole number. Source: Data from OECD.Stat (Patents Technology Development); accessed [10 05, 2018]), [https://stats.oecd.org/]. 